\title{
IBN TAIMIYAH'S VIEW ON GOVERNMENT INTERVENTION IN PRICING
}

\author{
Rika Pristian Fitri Astuti', Ali Mujahidin², Ifa Khoiria Ningrum ${ }^{3}$, \\ IKIP PGRI Bojonegoro ${ }^{1,2,3}$ \\ rika pristian@ikippgribojonegoro.ac.id ${ }^{1}$, \\ ali_mujahidin@ikippgribojonegoro.ac.id ${ }^{2}$, \\ ifa_khoirianingrum@ikippgribojonegoro.ac.id ${ }^{3}$
}

\begin{abstract}
This study is a literature review with the normative approach. To achieve the desired objectives, the authors collected data consisting of primary and secondary data. The data obtained through the previous discussion of some theses, books, websites, supported by guidelines of the Qur'an and Al-Hadith. In gathering the data, the researcher uses the method of a documentary, and with the way the method of indirect observation, by visiting the library in search of data. The result of this research that Ibn Taimiyyah had two views in pricing, the first is valid pricing, second is invalid pricing. And valid pricing can be done by the government to stabilize the economic condition which is called intervention. The goal of intervention is to ensure social justice and prosperity of society. Intervention mechanisms are divided into two, namely direct and indirect. Direct intervention in the form of Al-Hisbah, the character of the institution as a corporate planner, set the market mechanism that is not fair. Besides, in the particular circumstances that required the intervention price, for example when there was war and famine, so all the high-priced goods, or when there was speculation in the market, which requires the seller to sell goods, or when there was speculation in the market, which requires the seller to sell goods with high price levels. While the indirect intervention was implemented in the educational problems and the fulfillment of public facilities such as transport and communication.
\end{abstract}

\section{Keywords: Government, Intervention, Pricing, Ibn Taimiyyah}

\section{A. INTRODUCTION}

The market is the important element of human being's interaction to fulfill every life's needs. Actually, price is fixed by demand and supply of consumer to market, it makes the fair value of price because it's natural comes from a free market. Practically, in price-fixing, many factors influence the final value of the price of each product and will be injustice price if there is a deviation of the product. Therefore, Prophet Muhammad-Peace Be upon Him-did not fix the price when the price highly increased. It is Allah who fixes the price based upon the mechanical forces of supply and demand, these are therefore recognized as the will of God (Yusoff 2002). But another side from these case, we find some scientist in Islamic economic view more about price-fixing 
by other as Government. One of them is Ibn Taimiyyah, He thought many things about the market, price, and the government intervention on them because of many deviations in every side of the market.

Ibn Taimiyyah had a clear grasp of how, in a free market, prices are determined by forces of demand and supply (Dedi 2018). He said:

"Rise and fall in price are not always due to an injustice (zulm) by a certain individual. Sometimes, the reason for it is the deficiency in production or decline in import of goods in demand. Thus if the desire for it decreases, the price comes down. This scarcity or abundance may not be caused by the action of any individuals, it may have a cause not involving injustice, or something, it may have a cause that does involve injustice. It is Almighty God who creates desires in the hearts of people.

From that statement, it would appear that the just price always comes from demand and supply to the good. Otherwise, the case in Ibn Taimiyyah's time held rising prices to be the result of injustice on the part of the seller. Because of that, the government makes a role of price-fixing to help in controlling injustice prices because of many factors. Heri Sudarsono (2007); (Sari 2016) that Islamic history has that government controlling or it called by Al-Hisbah rise in the time of Rasulullah SAW. And in hadith explaining, it was called He just can fix the price when $\mathrm{He}$ finds disagreement problem between two people and needs in his helping to make a fair price.

In this case, The Government always control the price in the market, when the price rise without any factor from supply and demand, it will be an injustice (zulm), finally market will need Government Intervention in Pricing, although the authority of Pricing based on Government and market's element (seller and buyer) can't do anything except receive what has fixed by Government. In this problem, half of the Muslim theologians don't agree with price regulation by Government, like Ibnu Hazm and Ibnu Al-Atsir. Otherwise Ibn Taimiyyah had a different view about the government intervention in pricing than another Islamic economic scientist. He attributes price rise to either "a decrease in commodity" or an "increase in population". Decrease in commodity can be appropriately re-worded as a" fall in supply". Similarly, an "increase in population" is more likely to cause an increase in demand, so it can be re-worded as "rise in demand". An increase in price due to a fall in supply or a rise in demand is characterized as an act of Allah to indicate the impersonal nature of the market mechanism. In distinguishing between a price rise due to market forces and one due to injustice, such as hoarding, price corruption, and sellers hiding goods, Ibn Taimiyyah has located a ground for price regulation by The Government. Based on that case the writer will research the real of Ibn Taimiyyah's thought of government intervention in Price-Fixing. 


\section{B. THEORETICAL REVIEW}

\section{Ibn Taimiyyah's View on Economic Concept}

Ibn Taimiyyah's view on the Islamic Economic problem is clear. All of the economic activities are allowed except in the certain case that to be prohibited by Islamic law. In the limit of Islamic law prohibition, all of the people have known about the limitation of it as their maslahah and free action to the society in the transaction, or in an agreement between buyer and seller, and all the world activities transparency and justice . Ibn Taimiyyah has many concepts of economic, one of them is about Ibn Taimiyyah's concept in Partnership (Anita 2019).

Ibn Taimiyyah classifies all economic transactions and activities into two categories: Transactions based on justice (al-tasarrufat al- 'adliyah) and those based on generosity and benevolence (al-tasarrufat al-fadliyah). For the example are acts of lending, gift, and testament. The transactions based on justice are further divided into two categories, they are transactions through the exchange (al-mu'awwadhoh) and transactions through partnership (al-musyarakah). (Fasiha 2017).

\section{The Purpose of Government Intervention}

Such is mentioned above, one of the establishments of government is to enjoin what is commonly known as good (al-Ma'ruf), and forbid what is commonly known as evil (al-Munkar), the purpose of government intervention to market or objective of the Islamic state can be summarized as follows: to prevent injustice and to establish all-encompassing justice-legal, social, economic and political; to ensure freedom, dignity, and equality; to enable all Muslim men and women to realize the ethical goals of Islam, not in their beliefs, but also in the practical sphere of their lives; to ensure to all non-Muslim citizens complete physical security as well as complete freedom of religion, culture, and social development; to defend the country against internal subversion and external aggression; and to create an environment conducive to the teaching and preaching of the message of Islam (Rofiq 2018). In the other term, the primary purpose of government was to defend and protect the faith, not the state, because the basis of the Islamic state was ideological, not political, territorial, or ethnical (Islam 2016).

\section{The View on Price}

In Islamic history, the problem of the supervision in price emerged in the Prophet Muhammad SAW period personally. Two of four scholars, Hanbali and Syafi'i, stated that government did not have the right to determine the price Ibnu Qudamah AlMaqdisi was one of the argumentations Madzhab Hanbali wrote, that leader of the government did not have the authority to arrange the price for the inhabitants. The inhabitants might sell their things at the price of how many that were liked by them (Hilal 2014). Ibn Qudamah quoted hadith above and gave two reasons which are not 
allowed to arrange the price, both are: 1). the prophet Muhammad SAW had not appointed the price, despite the inhabitants to want. When then was permitted, definitely The Prophet Muhammad SAW will carry out. 2). appointed the price to be an injustice (zulm) that was banned. This involved proprietary rights someone inside anyone had the right to sell in the price how many, his origin agreed with his buyer. The supervision of the price will only aggravate this situation. That argument makes a summary, that a fixed price by other institutions will come with a different purpose. The high price, actually grows up from increasing demand and decreasing supply, the monitoring price will add the bad condition of it. (Hilal 2014).

\section{RESEARCH METHOD}

This is a research, which uses the conceptual approach analysis, which uses to know the mechanism of government intervention in pricing according to Ibn Taimiyyah's view.

a. Data Sources

To write this research, the writer needs some data classified into two-part: primary data sources are quoted from books and papers of Ibn Taimiyyah. Secondary data sources which are collected from books, magazine, newspapers, and website. The writer uses this data to know more information about Government Intervention, Price regulation, and Ibn Taimiyyah in supporting the primary data sources to get the latest news.

b. Method of Data Analysis

The researcher, uses the analysis method, they are indutive method and deductive method. 1). inductive method, it is a method with drawl of conclusion, which begins from declaration or special fact to the general conclusion. The researcher used this method to explain more from the argumentation of Islamic economic scientist as Ibn Taymiyyah in government intervention in pricing. 2). the deductive method is a thinking procession, which begins from the main declaration to the special declaration (Giordana 2018)(Soiferman, L.K. 2010). The researcher used this method to analyze Ibn Taimiyyah's view on Government Intervention in Pricing to conclude a justice law in this case. 3). The descriptive analysis content method is the analysis data that will be used to describe the detail of data from sources to conclude. The researcher will use the descriptive analysis content method to conclude Ibn Taimiyyah's view on Government Intervention in Pricing and will be a fair law of value of price in market mechanism now.

\section{RESULT AND DISCUSSION}

The view of government intervention in pricing according to Ibn Taimiyyah is the authority of government to control every side of the market and make the price- 
fixing to stabilize the market mechanism when all of the elements in the market disturbed by other hands such as speculation, accumulation of good and monopoly. When Rasulullah said to his society after they ask him to fix the price because priceincreasing disturb the society's welfare, that the only power is Allah who regulates the price and none can do the pricing except Him. Finally, some Islamic Scholar doesn't agree with government intervention in pricing because they thought that it can make an unjust decision when the seller can't fix their free value of price by themselves . But Ibn Taimiyyah brings this problem to fair condition with many reasons to make it allowed. He thought that the main problem in Rasulullah's prohibition of government intervention in pricing is the price increase in normal conditions when circulation of supply and demand run clearly (Nurfaizah 2020). While no power from the government intervenes it. Otherwise, in Ibn Taimiyyah's time the price-increasing not because of normal conditions but because of market distortion. So, he allows the government intervention in pricing with a certain case in injustice action.

\section{a. The Principle of Government Intervention in Pricing according to Ibn Taimiyyah}

Price control and administrative fixation have been controversial matters in the history of Islamic economic thought. A comprehensive treatment of the subject is found with Ibn Taimiyyah and he discusses it deeply and makes a great analysis based on economic viewing. The issue grows up in the sixteenth century because the sixteenth century saw a great number of fluctuations in prices. This must-have attracted the attention of thinkers of the period to find out the reason behind such fluctuations, and they did it. The historians who report such incidences also point out the reasons. They were fully aware that it is the demand and supply of a good that determine the price and changes in these two market forces result in fluctuations in the price (Maulidizen 2019)

Another problem comes from the black market as monopoly playing. It is very important to curb the urge to monopolize markets while fostering an atmosphere for a liberal economy. The principle is, then, not to intervene if the price reflects normal supply and demand conditions. The Prophet in an incident related to importation reportedly said: "The following which is a brief translation: "It is Allah who regulates prices, who gives shortage as well as abundance, and who gives sustenance".

This constitutes was evidence against price controls under some circumstances. The hadith teaches us, if intervention turns out to be prohibitive, there will not be a supply of any amount of foreign goods. This leads to a situation of scarcity and practices of the black market. Thus, for the benefit of the society the Prophet encouraged suppliers of goods, wanted liberal market conditions to prevail to prevent scarcity60. Nevertheless, the principle set by the above-mentioned Hadith does not rule out government intervention in cases of monopolistic practices. Prophet's 
objection to price controls is only subject to normal price fluctuations generated by normal supply and demand conditions. Ibn Taimiyyah and Ibn al-Qayyim too, interpreted the very same Hadith the way we have expressed above.

Ibn Taimiyyah explain the reason for the Prophet's prohibition in government intervention, those are :

1) The price mechanism in a normal condition from supply and demand interaction in that time, it's not come from imperfection market.

2) The price mechanism does not lose the society, since their needs were served.(Setiawan 2015)

Based on these reasons, Ibn Taimiyyah makes other viewing in government intervention in pricing when all of the conditions in his time different from Prophet's time. A prevailing view in Ibn Taimiyyah's time held rising prices to be the result of injustice or malpractice on the part of sellers. The actual word used by him is zulm, which means transgression or injustice. Here, it is used in the sense of manipulation by sellers leading to imperfection in the market. Based on that case is price mechanism can make the loss of society or disturbing primary needs serving of society, the government intervention must solve it. The government intervention not just action in price-fixing but also intervene in market mechanism like to serve goods stock sufficiently (Baroroh 2018). If price increasing in the market because of unjust person act by accumulating goods to make the scarcity of stock and its influence in high pricing, then half of the famous scholar as Ibn Qudamah, Ibn Taimiyyah, and also Ibn Qayyim al-Jauziah allow the price regulation by the government. Ibn Taimiyyah gives the proof that Rasulullah regulates the price once a time when $\mathrm{He}$ saw the disagreement between two-person about the tree which grow in his neighbor's field and his neighbour felt disturbed by others feet that always walk on his field.

Rasulullah asks the owner of the tree to sell the tree to his neighbor with just compensation to him. Finally, Rasulullah allows the neighbor to cut the tree. And in other cases, Rasulullah fixes the price in buying his slave from his enemy. And then he discusses hardly price-fixing based on Islamic Law in the market mechanism. Besides, Ibn Taimiyyah distinguishes: "two types of price fixing-unjust and invalid, and just and valid." Prohibited and unjust price-fixing is that which has been done in the wake of price rice caused by the free play of competitive market forces- shortage of supply or increase of demand. Though Ibn Taimiyyah never uses the term "competition" nor mention all the conditions of perfect competition in clear terms in any place, it is clear from his view on the functioning of the market, expressed a different point in Al-Hisbah, that he had at least some of the conditions of perfect competition in mind. For example, he writes: "to force people to sell objects which it is not obligatory to sell, or restrict them from selling a permissible object, are injustice and injustice is unlawful." 
This means people are fully in freedom to enter or quit the market. Ibn Taimiyyah advocates exclusion of the monopolistic element from the market and therefore against any collusion between professional men or any group of seller and buyers67. He emphasizes knowledge of the market and the commodity, as the contract of sale and purchase depends on consent requires knowledge and understanding. Homogeneity and standardization of product are advocated in his condemnation of adulteration of the product and of fraud and deception in its presentation for sale. He had a clear conception of a well-behaved, orderly market, in which knowledge, honesty and fair play, and freedom of choice were the essential elements (Salim, Muharir, and Hermalia 2021).

But in times of emergency, such as famine, Ibn Taimiyyah recommends pricefixing by the government. In price-fixing, a distinction must be made between local traders holding goods in stock and outside suppliers of those goods, as no price may be fixed on the merchandise of the latter. But they may be asked to sell as their fellow importers are selling. Price control would hurt imported supplies, whereas for locally available goods price control need not, necessarily, harm buyers. As for pricing in emergencies, even modern economists accept that price regulation is more effective and successful in such conditions than others. The famous economist Paul A. Samuelson, for example, writes: "Patriotism is more effective in motivating people to brief acts of intense heroism than to putting up day after day with an uncomfortable situation". He goes on: "Such emergency measures work very well in emergencies but may create more and more distortions the longer they are in effect. Economists, therefore, tend to recommend that such direct fiats be reserved for emergency periods and not be squandered on minor peacetime situations".

According to the ijtihad analogy (qiyas), the writer takes a short analysis that the damage condition in society come from unjust seller and speculation of the market mechanism. These all will be solved by government intervention in pricing, to organize the black market stability and even Rosululla as a state leader make forceselling to stabilize the economic condition in his time because of some injustice person. It makes the evidence of government authority in the market mechanism. That they have a responsibility to serve society as well as they can. From the explanation above, Ibn Taimiyyah gets his basic principle to allow the government intervention in pricing, because not all of the mechanism of the market can run every time. If the government doesn't organize the market problem, we will find so many black playing of market mechanism loss control, even in demand or supply and also in price level which will destroy the social life.

\section{The reason for government intervention in pricing according to Ibn Taimiyyah}

Ibn Taimiyyah said about controlling the prices of factors production. In fact, in this market, he applied the same rule as in the goods market. He says that if people 
need the services of artisans and cultivators and they refuse to offer them or create some sort of imperfection in the market, the state should fix their prices. And the purpose of this price control is to protect the employers and employees from the exploitation of each other.

Ibn Taimiyyah though this involvement of government in price-fixing have the basic principle from Islamic Teaching, and he believes the government has a right to control the state especially in price, those are :

1) In times of emergency, such as famine, Ibn Taimiyyah recommends price-fixing by the government and forced sale of essential commodities like foodstuffs. $71 \mathrm{He}$ says:

"It is for the authority to compel a person to sell his goods at a fair price when people need it. For example, when he has surplus food and people are faced with starvation, he will be forced to sell at a just price".73

According to him, the compulsion to sell is impermissible without sufficient reason, but with such reason it is permissible.

2) Apart from conditions of drought and war, Ibn Taimiyyah recommends pricefixing by the government whenever imperfections enter the market.

\section{E. CONCLUSION}

After collecting data, the researcher can be concluded as follows:

1. Ibn Taimiyyah's view on government intervention in pricing is that government has the authority to control the market mechanism and also to fix the price in a certain condition. When all of the market elements are disturbed by the imperfect markets such as monopoly, good accumulations, and speculation. But when the circulation of supply and demand runs clearly, government intervention is prohibited.

2. The application of government intervention in market are government authority to fix or to change the value of normal price directly, and to add market supply by importing product of serving the increased demand in order to stabilize the condition of market. The goal of these government activities is to stabilize the price circulation in market because market distortion.

\section{DAFTAR PUSTAKA}

Anita, Dewy. (2019). "Relevansi Pemikiran Ibnu Taimiyah Terhadap Regulasi Harga Di Indonesia.” Jurnal Pemikiran Islam 3(1):39-64.

Baroroh, Nurdin. (2018). "Harga Dan Mekanisme Pasar (Studi Perbandingan Ibn Taimiyah Dan Ibn Khaldun).” Az Zarqa’ 10(2).

Dedi, Syarial. (2018). “Ekonomi Dan Penguasa (Pemikiran Ibn Taimiyah Tentang 
Mekanisme Pasar).” AL-FALAH : Journal of Islamic Economics 3(1):73. doi: 10.29240/jie.v3i1.442.

Fasiha. (2017). “Al-Amwal : Journal of Islamic Economic Law September 2017, Vol. 2, No. 2 Http://Www.Iainpalopo.Ac.Id/Index.Php/Amwal.” Islamic Economic 2(2):111-27.

Giordana, Marco. (2018). "Fintech Sector: Business Model Analysis in the Mobile Payments Area.” (April):159.

Hilal, Syamsul. (2014). "Konsep Harga Dalam Ekonomi Islam (Telah Pemikiran Ibn Taimiyah).” Asas 6(2):16-28.

Islam, Muhammad Hifdil. (2016). "Ibnu Taimiyah and His Concept of Economy." Iqtishoduna 7(1):15-33.

Maulidizen, Ahmad. (2019). "Economic Thought of Ibn Taimiyah and Relevance to the World Economic and Community Economic System.” Esensia Jurnal IlmuIlmu Ushuludin 20(2):131-46.

Nurfaizah, Khanifah. (2020). "Government Intervention in Determining Prices According To Ibn Taimiyah'S.” Airlangga International Journal of Islamic Economics and Finance 2(2):97. doi: 10.20473/aijief.v2i2.20821.

Rofiq, M. Khoirur. (2018). "Pemikiran Ekonomi Islam Ibnu Taimiyah.” An-Nawa, Jurnal Hukum Islam XXII(1):28-60.

Salim, Amir, Muharir Muharir, and Alda Hermalia. (2021). "Pemikiran Ibnu Taimiyah Dalam Harga, Pasar Dan Hak Milik.” Ekonomica Sharia: Jurnal Pemikiran Dan Pengembangan Perbankan Syariah 6(2):155-66. doi: 10.36908/esha.v6i2.207.

Sari, Sepri Wulan. (2016). "Perkembangan Dan Pemikiran Uang Dari Masa Ke Masa." An-Nisbah: Jurnal Ekonomi Syariah 3(1). doi: 10.21274/an.2016.3.1.39-58.

Setiawan, Romi Adetio. (2015). "The Relevance Of Ibn Taymiyyah Economics.” $A l$ Intaj 13-22.

Soiferman, L.K. (2010). "Inductive and Deductive Research Approaches.” (April):123.

Yusoff, Nik Mohamed Affandi bin Nik. (2002). Islam and Business. Vol. 2. 